\title{
KEWENANGAN PEMERINTAH PUSAT DENGAN PEMERINTAH DAERAH DALAM PELAKSANAAN KEGIATAN ALOKASI DANA CUKAI HASIL TEMBAKAU
}

\author{
Insana Meliya Dwi Cipta Aprila Sari \\ STKIP PGRI Bangkalan \\ insanameliya@gmail.com
}

\begin{abstract}
Implementation Of The Allocation Of Profit-Sharing Fund Of Tobacco-Product Duty (Dbh-Cht) Policy Is A Concurrent Governmental Affair. To Some Extent, It Is Mutually Carried Out By Central Government And Local Government, However, There Are Some Components That Exclusively Become The Authority Of Central Government Whereas The Other Ones Are Under The Authority Of Provincial/Regency/Town Government. Governmental Affairs Under The Authority Of Provincial And Regency/Town Governments Are Based On The Principles Of Externality, Accountability, And Efficiency. Such Affairs Consist Of Compulsory Affairs And Optional Ones.
\end{abstract}

Keywords: profit-sharing fund of tobacco-product duty, concurrent governmental affair, the authority of central government, the authority of provincial/regency/town government.

\begin{abstract}
Abstrak
Pelaksanaan Kebijakan Pengalokasian Dana Bagi Hasil Cukai Hasil Tembakau Merupakan Urusan Pemerintahan Yang Concurrent. Pada Beberapa Hal Kebijakan Itu Dilaksanakan Bersama-Sama Oleh Pemerintah Pusat Dengan Pemerintah Daerah, Tetapi Ada Beberapa Bagian Yang Murni Menjadi Kewenangan Pemerintah Pusat Sementara Ada Beberapa Hal Lain Yang Menjadi Kewenangan Pemerintah Provinsi/Kabupaten/Kota. Urusan-Urusan Pemerintahan Yang Menjadi Kewenangan Pemerintah Provinsi, Kabupaten/Kota Didasarkan Atas Prinsip Eksternalitas, Akuntabilitas, Dan Efisiensi. Urusan Tersebut Terdiri Atas Urusan Wajib Dan Pilihan.

Kata kunci: dana bagi hasil cukai hasil tembakau (Dbh-Cht), urusan pemerintahan concurrent, kewenangan pemerintah pusat, kewenangan pemerintahan provinsi/kabupaten/kota.
\end{abstract}

\section{Pendahuluan}

Cukai merupakan pungutan negara yang di APBN masuk dalam golongan pendapatan pajak dalam negeri. Cukai termasuk golongan pajak pusat yang dipungut oleh pemerintah pusat yang dalam pelaksanaannya dikelola oleh Direktorat Jenderal Bea dan Cukai (DJBC). Lembaga administrasi pajak yang tugasnya melaksanakan pengelolaan terhadap pajak pusat seperti bea masuk, bea 
keluar, dan cukai. DJBC melaksanakan pemungutan pajak berdasarkan hukum pajak formal yaitu Undang-Undang Nomor 10 Tahun 1995 tentang Kepabeanan yang kemudian diubah dengan Undang-Undang Nomor 17 Tahun 2006 tentang Kepabeanan (UU Kepabeanan) dan untuk Cukai berdasarkan Undang-Undang Nomor 11 Tahun 1995 sebagaimana diubah dengan Undang-Undang Nomor 39 Tahun 2007 tentang Perubahan Atas Undang-Undang Nomor 11 Tahun 1995 tentang Cukai (UU Cukai). ${ }^{1}$

Kebijakan dalam mengoptimalkan penerimaan negara dari sektor cukai baik melalui kebijakan ekstensifikasi dan intensifikasi cukai; merupakan upaya yang lebih menekankan pada pengaturan pendapatan dan belanja pemerintah. Hal ini karena Cukai khususnya Cukai Hasil Tembakau (CHT) merupakan salah satu sumber pendapatan negara (pajak dalam negeri), maka pemerintah melalui kebijakan ekstensifikasi dan intensifikasi cukai berupaya agar penerimaan negara dari cukai mengalami peningkatan dari tahun ke tahun. Pendapatan cukai negara mendanai belanja/pengeluaran negara dalam pembangunan nasional.

Kebijakan pemerintah pusat atas alokasi dana CHT ke daerah disamping meningkatkan penerimaan dari sektor CHT sekaligus mengatasi dampak rokok terhadap kesehatan; seperti adanya beberapa program dan kegiatan yang diagendakan dalam kebijakan tersebut. Menurut Pasal 66 A (Ayat 1) UU Cukai ; bahwa alokasi dana CHT untuk mendanai kegiatan: peningkatan kualitas bahan baku, pembinaan industri, pembinaan lingkungan sosial, sosialisasi ketentuan dibidang cukai, dan/atau pemberantasan barang kena cukai ilegal. Berikut ini akan dibahas mengenai hubungan kewenangan antara pemerintah pusat dengan pemerintah daerah dalam pelaksanaan program/kegiatan alokasi dana cukai hasil tembakau.

Kebijakan pemerintah Tahun Anggaran (TA) 2008 mengalokasikan 2\% dari pendapatan CHT yang dibuat di Indonesia, dialokasikan kedaerah provinsi, kabupaten/kota penghasil CHT, untuk melaksanakan penugasan dari pemerintah antara lain: mengurangi cukai palsu/cukai ilegal, sosialisasi peraturan di bidang

${ }^{1}$ Sugianto, Pengantar Kepabeanan dan Cukai, Jakarta: Grasindo Widiasarana, 2008, h. 4. 
cukai, dan pemetaan industri rokok melalui beberapa program dan kegiatan dari pasal 66 A (Ayat 1) UU Cukai. DBH-CHT adalah dana yang bersumber dari pendapatan APBN, tepatnya adalah penerimaan negara dari CHT yang dibuat di Indonesia; dibagikan kepada provinsi penghasil CHT sebesar 2\% (dua persen); (kemudian Th 2010 meliputi juga provinsi penghasil tembakau); membantu daerah-daerah tersebut melaksanakan kebijakan pemerintah pusat, guna meningkatkan penerimaan negara dari sektor CHT serta mengatasi dampak rokok terhadap kesehatan.

DBH-CHT merupakan bentuk kebijakan pemerintah dalam mengelola anggaran belanja negara; dengan cara mengalokasikan sebagian dari pendapatan negara dalam bentuk anggaran transfer ke daerah. Hal ini dilakukan mengingat berfluktuasinya penerimaan negara dari sektor migas maka diperlukan upaya peningkatan dana yang berasal dari pajak dalam negeri, khususnya dalam hal ini penerimaan dari cukai. Dengan uraian tersebut kebijakan dibidang cukai merupakan salah satu bentuk kebijakan fiskal (kebijakan ekonomi); karena memenuhi instrumen kebijakan fiskal yaitu penerimaan dan pengeluaran pemerintah yang berhubungan erat dengan pajak mengarahkan kondisi perekonomian menjadi lebih baik dengan jalan "mengubah" penerimaan dan pengeluaran pemerintah agar kondusif mendanai pembangunan.

Dengan demikian cukai masuk dalam lingkup fiskal; Pasal 10 (Ayat 3) Undang-Undang Nomor 32 Tahun 2004 tentang Pemerintahan Daerah (UU No. 32/2004); fiskal merupakan salah satu urusan pemerintahan yang menjadi kewenangan pemerintah pusat; maka dalam menyelenggarakannya, pemerintah pusat dapat melimpahkan sebagian urusan pemerintahan kepada perangkat pemerintah atau wakil pemerintah di daerah. Dalam menyelenggarakan pemerintahan, presiden dibantu oleh menteri-menteri. Menteri yang membidangi urusan fiskal adalah menteri keuangan yang memimpin departemen keuangan, berada dibawah dan bertanggungjawab kepada presiden.

Dalam rangka pelaksanaan kekuasaan atas pengelolaan fiskal, Menteri Keuangan mempunyai tugas antara lain: a) Menyusun rancangan APBN dan rancangan perubahan APBN; b) Melaksanakan pemungutan pendapatan negara 
yang telah ditetapkan dengan undang-undang; c) Mengesahkan dokumen pelaksanaan anggaran. (Lihat Pasal 8 Undang-Undang Nomor 17 Tahun 2003 tentang Keuangan Negara).

Dalam peraturan menteri keuangan No.100/PMK.01/2008 departemen keuangan mempunyai tugas membantu presiden dalam menyelenggarakan sebagian tugas pemerintahan dibidang keuangan dan kekayaan negara meliputi:kegiatan dan usaha-usaha menghimpun, mengalokasikan, mengarahkan dan menggerakkan dana, serta membina kekayaan negara dalam rangka pelaksanaan kebijaksanaan umum dibidang fiskal serta kebijaksanaan neraca pembayaran. Departemen keuangan sebagai pengelola keuangan dan kekayaan negara membagi kebijakan fiskal dalam Lima bidang utama yaitu: pendapatan negara, belanja negara, pembiayaan negara, kekayaan negara dan sistem pengelolaan keuangan negara.

Kewenangan pemerintah pusat dalam pelaksanaan DBH-CHT melibatkan beberapa ditjen dari Depkeu antara lain adalah Ditjen Bea dan Cukai (DJBC), Ditjen Perimbangan Keuangan (DJPK), dan Ditjen Perbendaharaan (DJP), sebenarnya masih ada beberapa direktorat dari Depkeu yang sedikit banyak juga berperan dalam merealisasikan kebijakan pemerintah ini, tapi karena keterbatasan waktu maka pembahasan hanya sebatas Tiga direktorat tersebut.

DJBC kementerian keuangan bertugas merumuskan serta melaksanakan kebijakan dan standardisasi teknis dibidang kepabeanan dan cukai berdasarkan kebijakan yang ditetapkan oleh menteri keuangan (berdasarkan peraturan perundangan). Dalam DJBC terdapat beberapa direktorat yang khusus membidangi masalah cukai. ${ }^{2}$

Seperti dikemukakan diatas bahwa departemen keuangan termasuk Tipe Holding Company; untuk Tipe Departemen yang demikian maka penyelenggara tugas dan fungsi departemen didaerah dilaksanakan oleh Kantor Wilayah Direktorat Jenderal. Dalam Peraturan Presiden Nomor 22 Tahun 2007 dan PMK

\footnotetext{
${ }^{2}$ Peraturan Menteri keuangan No. 100/PMK.01/2008 tentang organisasi dan tata kerja departemen keuangan.
} 
Nomor 68.PMK.01/2007 tentang organisasi dan tata kerja instansi vertikal Ditjen Bea \& Cukai, disebutkan bahwa Kantor wilayah DJBC merupakan salah satu instansi vertikal dari DJBC. Semakin memperjelas bahwa penyelenggaraan cukai di daerah telah terjadi pelimpahan wewenang pemerintahan dari pemerintah pusat (DJBC) kepada instansi vertikal di daerah; Asas dekonsentrasi. Dekonsentrasi adalah pelimpahan wewenang pemerintahan oleh pemerintah kepada gubernur sebagai wakil pemerintah dan/atau kepada instansi vertikal diwilayah tertentu. ${ }^{3}$

Selanjutnya Pasal 228 ayat (1) UU No. 32/2004 bahwa penyelenggaraan urusan pemerintahan yang menjadi wewenang pemerintah sebagaimana dimaksud dalam Pasal 10 ayat (3) UU No. 32/2004 (termasuk diantaranya adalah fiskal); yang didekonsentrasikan, dilaksanakan oleh instansi vertikal didaerah. Kemudian Pasal 11 Peraturan Pemerintah Nomor 7 Tahun 2008 tentang Dekonsentrasi dan Tugas Pembantuan (PP No. 7/2008) yang diantara ketentuannya membahas penyelenggaraan dekonsentrasi; bahwa pelimpahan sebagian urusan pemerintahan dapat dilakukan kepada gubernur, selain dilimpahkan kepada gubernur sebagian urusan pemerintahan dapat pula dilimpahkan kepada:a) instansi vertikal; b) pejabat pemerintah di daerah.

Sesuai Peraturan Presiden Nomor 22 Tahun 2007 Instansi Vertikal Ditjen Bea \& Cukai terdiri dari: (a)Kantor Wilayah DJBC; (b)Kantor Pelayanan Utama Bea dan Cukai; (c)Kantor pengawasan dan Pelayanan Bea dan Cukai.

Instansi Vertikal departemen keuangan yang menyelenggarakan tugas pokok dan fungsi Ditjen Bea \& Cukai di Jawa Timur adalah: 1)Kantor Wilayah XI DJBC Jatim I yang berlokasi di Tanjung Perak Surabaya (Kepabeanan-ekspor impor; 2)Kantor Wilayah XII DJBC Jatim II yang berlokasi di Malang (urusan Cukai); 3)Kantor Pengawasan dan Pelayanan Bea dan Cukai/KPPBC (Tipe madya) yang berlokasi di Malang; 4)Kantor Pengawasan dan Pelayanan Bea dan Cukai/KPPBC yang berlokasi di Juanda Km 3-4 sda Surabaya (Cukai).

Instansi vertikal departemen adalah perangkat departemen sebagai penyelenggara tugas pokok dan fungsi departemen di daerah/wilayah yang

\footnotetext{
${ }^{3}$ Ketentuan Umum Pasal 1 No.8 UU.No. 32/2004 tentang Pemerintahan Daerah.
} 
mengurus urusan pemerintahan yang tidak diserahkan kepada daerah, dalam wilayah tertentu dalam rangka dekonsentrasi.

Instansi Vertikal yang menyelenggarakan urusan pemerintahan di provinsi dan kabupaten/kota wajib: ${ }^{4}$

a. berkoordinasi dengan gubernur atau bupati/walikota dan instansi terkait dalam perencanaan, pendanaan, pelaksanaan, evaluasi dan pelaporan, sesuai dengan norma, standar, pedoman, arahan, dan kebijakan pemerintah yang diselaraskan dengan perencanaan tata ruang dan program pembangunan daerah serta kebijakan pemerintah daerah lainnya;

b. memberikan saran kepada menteri/pimpinan lembaga dan gubernur atau bupati/walikota berkenaan dengan penyelenggaraan urusan pemerintahan yang dilimpahkan.

\section{Pembahasan}

Pasal 66 A UU Cukai bahwa penerimaan negara dari CHT yang dibuat di Indonesia dibagikan kepada provinsi penghasil CHT sebesar $2 \%$ yang kemudian disebut dengan DBH-CHT yang pertama kali dialokasikan pada TA 2008. Kebijakan pemerintah ini dilakukan karena penerimaan cukai dari tahun ke tahun selalu mengalam peningkatan yang signifikan, terutama CHT. Tahun anggaran 2008 kontribusi cukai terhadap penerimaan perpajakan (Pajak Dalam Negeri) sebesar Rp 44.426.530.000.000,- (empat puluh empat triliun empat ratus dua puluh enam milliar lima ratus tiga puluh juta) dan sumbangan CHT terhadap penerimaan cukai secara keseluruhan sebesar 98\% lebih yakni mencapai Rp 43.571.000.000.000,-. Begitu pula di APBN TA 2009 (Undang-Undang Nomor 41 Tahun 2008 tentang Anggaran Pendapatan dan Belanja Negara Tahun Anggaran 2009); penerimaan negara dari pendapatan cukai naik dibandingkan Tahun 2008 menjadi Rp 49.494.700.000.000,- dan CHT menyumbang Rp 48.240.100.000.000,- Kemudian APBN TA 2010 (Undang-Undang .Nomor 47 Tahun 2009 tentang Anggaran Pendapatan dan Belanja Negara Tahun Anggaran 2010) pendapatan cukai mencapai Rp 57.289.169.000.000,- dari jumlah tersebut Rp 55.926.553.000.000,- berasal dari pendapatan Cukai hasil tembakau.

\footnotetext{
${ }^{4}$ Peraturan Pemerintah RI No.7/2008 tentang Dekonsentrasi dan Tugas Pembantuan.
} 
Hasil memuaskan (peningkatan signifikan dari tahun ke tahun) pendapatan cukai ini berkat kerjasama/partisipasi dari berbagai pihak, tentunya tidak lepas dari hasil kinerja Ditjen Bea \& Cukai (DJBC), Instansi Vertikal DJBC serta UPT (Unit Pelaksana Teknis) di daerah (sebagai Unit Pelaksana Tugas Teknis penunjang Direktorat Jenderal/badan. ${ }^{5}$ Dalam Ditjen Bea \& Cukai terdapat UPT yakni: 1) Pangkalan Sarana Operasi Bea \& Cukai; 2) Balai Pengujian dan Identifikasi Barang.

Dalam pelaksanaan DBH CHT Ditjen Bea dan Cukai mempunyai peran hanya sebagai pemberi data tentang kontribusi dari masing-masing daerah provinsi penghasil CHT terhadap penerimaan negara dari sektor cukai, dan menjadi salah satu dasar dalam penentuan jumlah DBH CHT yang akan dialokasikan ke masing-masing daerah penghasil CHT; kemudian dilanjutkan TA 2010 yang pengalokasiannya lebih diperluas lagi, yaitu selain untuk daerah penghasil CHT juga untuk daerah penghasil Tembakau; mengingat putusan Mahkamah Konstitusi atas permohonan pengujian/constitutional review Gubernur NTB H.M Zainul Majdi terhadap Pasal 66 A UU Cukai. Mahkamah Konstitusi memutuskan, alokasi DBH CHT tidak hanya untuk daerah penghasil CHT saja tetapi juga untuk daerah penghasil tembakau; pengalokasian DBH CHT untuk provinsi penghasil tembakau tersebut harus dipenuhi paling lambat mulai TA 2010 dengan porsi pembagian tetap seperti semula sebesar $2 \%$ dari pendapatan CHT yang dibuat di Indonesia.

Provinsi Jawa Timur dijadikan sebagai objek penelitian karena TA 2008, 2009, 2010, dan 2011 total alokasi dana CHT untuk provinsi ini merupakan yang terbesar dibandingkan dana yang dilokasikan ke daerah penghasil $\mathrm{CHT} /$ penghasil tembakau lainnya; yaitu TA`2008 sejumlah Rp 135.849.855.000,-, TA 2009 sebesar Rp 599.357.180.000,00 (meningkat signifikan dibandingkan Th 2008), TA 2010 sebesar Rp 613.451.367.661,- dan TA 2011 sebesar Rp 618.750.828.561,-dana tersebut kemudian dialokasikan kepada provinsi/kabupaten/kota di Jawa Timur. Ada 5 daerah yang mendapat alokasi

\footnotetext{
${ }^{5}$ Peraturan Menteri Keuangan No.100/PMK.01/2008, Pasal 21 dan 27.
} 
dana CHT(Th.2008) dan DBH-CHT Th.2009 yaitu Provinsi Sumatra Utara, Jabar, Jateng, Jatim, dan D.I.Yogyakarta (sebagai daerah penghasil CHT). Kemudian Th 2010 menjadi 19 daerah dan Th 2011 menjadi 20 daerah yang mendapat alokasi DBH-CHT (meliputi daerah penghasil tembakau dan penghasil CHT) ${ }^{6}$. Selanjutnya gubernur berwenang mengatur pembagian DBH-CHT tersebut kepada kabupaten/kota yang ada diwilayahnya.

Berikut ini mekanisme hubungan kewenangan dalam pelaksanaan kebijakan DBH-CHT .

Peran Ditjen Bea \& Cukai (DJBC) dalam Pelaksanaan Program/kegiatan DBHCHT; misalnya: Dalam mekanisme penetapan alokasi DBH-CHT per daerah; (a)DJBC memberikan data perkiraan CHT per provinsi dan data perkiraan DBH CHT per provinsi; (b)DJBC mengirim surat kepada Kantor Wilayah DJBC; menindaklanjuti surat dari Direktorat Jenderal Perimbangan Keuangan (DJPK) tentang permohonan agar DJBC mengizinkan Kantor Wilayah DJBC memberikan data perkiraan CHT per Kabupaten/kota; (c)Kantor wilayah DJBC (Kw CJBC) mengirimkan surat mengenai data perkiraan CHT per kabupaten/kota kepada gubernur daerah penghasil CHT; selanjutnya data perkiraan tersebut menjadi dasar bagi gubernur untuk mengatur dan menetapkan pembagian DBH-CHT per provinsi/kabupaten/kota; namun jika sampai deadline Kw DJBC dalam hal ini Kantor Pengawasan dan Pelayanan Bea dan Cukai belum menyampaikan data perkiraan CHT per daerah maka menjadi kewenangan gubernur untuk membagi DBH-CHT per daerah.

Gubernur mengelola dan menggunakan DBH-CHT dan mengatur pembagian DBH-CHT kepada bupati/walikota didaerahnya masingmasing berdasarkan besaran kontribusi terhadap penerimaan CHT-nya. Ayat selanjutnya menyatakan bahwa Pembagian DBH-CHT tersebut dilakukan dengan persetujuan Menteri Keuangan RI; dengan komposisi $30 \%$ untuk provinsi penghasil, $40 \%$ untuk kabupaten/kota daerah penghasil, dan 30\% untuk kabupaten/kota lainnya. (Lihat Pasal 66A (Ayat 3 dan 4 ) UU. No.39/2007 tentang Perubahan atas UU.No.11/1995 tentang Cukai)

\footnotetext{
${ }^{6}$ Permenkeu No.66/PMK.07/2010 dan Permenkeu No.33/PMK.07/2011 tentang Alokasi Sementara.
} 
Ditjen Perimbangan Keuangan (DJPK) berdasarkan Peraturan Menteri Keuangan No.100/PMK.01/2008 bertugas merumuskan serta melaksanakan kebijakan dan standarisasi teknis di bidang perimbangan keuangan antara pemerintah pusat dan daerah sesuai dengan kebijakan yang ditetapkan oleh menteri keuangan dan berdasarkan peraturan perundang-undangan yang berlaku. Alokasi dana CHT TA 2008 dianggarkan dalam belanja negara pada kelompok dana penyesuaian; sedangkan DBH-CHT mulai Th 2009, 2010, 2011dianggarkan di APBN sebagai bagian dari dana perimbangan; masuk dalam komponen dana bagi hasil. DBH-CHT di APBN TA 2009(UU.No.41/2008) sebesar Rp964.802.000.000,-. DBH-CHT pada APBN TA2010 (UU.No.47/2009)sebesar Rp1.118.531.100.000,- kemudian DBH-CHT di APBN TA2011(UU.No.10/2010) sebesar Rp1.201.357.960.000,00. DBHCHT masuk dalam kebijakan dan standardisasi yang perumusan dan pelaksanaannya terkait dengan tugas dan fungsi DJPK). Sesuai dengan PMK No.100/PMK.01/2008 DJPK menjalankan fungsi antara lain; 1)Perannya dalam merumuskan kebijakan dibidang perimbangan keuangan antara pemerintah pusat dan daerah; 2)Menjalankan tugas-tugas terkait dengan pelaksanaan kebijakan dibidang perimbangan keuangan antara pemerintah pusat dan daerah; 3)Perumusan standar, norma, pedoman, kriteria, dan prosedur dibidang perimbangan keuangan antara pemerintah pusat dan daerah; 4)Pemberian bimbingan teknis dan evaluasi dibidang perimbangan keuangan antara pemerintah pusat dan daerah. Peran Ditjen Perimbangan Keuangan (DJPK) dalam pelaksanaan DBH CHT; antara lain:

Mekanisme Penetapan Alokasi DBH CHT; a) DJPK menerima data CHT \& DBH CHT per provinsi dari DJBC; b) Selanjutnya DJPK menindaklanjuti dengan mengirim surat pemberitahuan mengenai $\mathrm{DBH}$ CHT kepada provinsi penghasil CHT melalui gubernur; c) DJPK mengirimkan surat ke DJBC yang isinya mengajukan surat permohonan agar DJBC mengizinkan kantor wilayah DJBC memberikan data perkiraan tentang CHT per kabupaten/kota kepada gubernur yang ada diwilayahnya;

d) Kanwil DJBC mengirimkan surat perkiraan CHT per kabupaten/kota 
kepada gubernur daerah penghasil CHT; e) Gubernur mengeluarkan peraturan kebijakan berupa peraturan gubernur tentang pembagian DBHCHT untuk provinsi/kabupaten/kota yang ada diwilayahnya kemudian dikirimkan kepada DJPK; f)DJPK atas nama menteri keuangan menerbitkan peraturan kebijaksanaan berupa permenkeu tentang alokasi dana CHT TA dan dilampiri dengan penetapan menteri keuangan mengenai alokasi dana CHT untuk provinsi/kabupaten/kota; representasi dari persetujuan menkeu atas pembagian DBH-CHT kepada provinsi/kabupaten/kota yang sebelumnya ditetapkan dalam peraturan gubernur.

DJPK menyampaikan standar, norma, pedoman, kriteria, dan prosedur dalam pelaksanaan DBH CHT; contohnya yang diselenggarakan di Surabaya, 23 Desember 2008 dalam Rapat Pembahasan Pembagian \& Program Kerja DBH-CHT.

Selanjutnya peran Direktorat Jenderal Perbendaharaan (DJP) mempunyai tugas merumuskan serta melaksanakan kebijakan dan standardisasi teknis dibidang Perbendaharaan Negara sesuai dengan kebijakan yang ditetapkan oleh Menteri Keuangan dan berdasarkan peraturan perundang-undangan yang berlaku ${ }^{7}$.

Dalam pelaksanaan DBH CHT peran Ditjen Perbendaharaan antara lain tampak dalam mekanisme pelaksanaan anggaran Transfer Ke daerah; yaitu berdasarkan Peraturan Menteri Keuangan (Permenkeu), Dirjen Perimbangan Keuangan menerbitkan DIPA (Daftar Isian Pelaksanaan Anggaran) alokasi dana CHT, DIPA kemudian disampaikan kepada Dirjen Perbendaharaan untuk mendapatkan pengesahan. ${ }^{8}$ Pengesahan atas DIPA tersebut merupakan dasar pelaksanaan anggaran transfer ke daerah. Selain itu dalam Pasal 9 Permenkeu No.21/PMK.07/2009 mengatur bahwa DJP memberikan pengesahan atas penetapan perubahan/revisi DIPA yang telah dilakukan oleh DJPK atas nama

\footnotetext{
${ }^{7}$ Lihat Peraturan Menteri Keuangan No.100/PMK.01/2008 tentang Susunan Organisasi, dan tata kerja Departemen Keuangan.

${ }^{8}$ Peraturan Menteri Keuangan No.60/PMK.07/2008, tentang Dana Alokasi Cukai Hasil Tembakau TA 2008, Pasal 6 ayat (1) \& (2).
} 
menteri keuangan. Perubahan atau revisi DIPA yang telah mendapatkan pengesahan tersebut merupakan dasar pelaksanaan Anggaran Transfer Kedaerah. Peran Ditjen Perbendaharaan dalam pelaksanaan alokasi dana CHT dapat dilihat di Pasal 6 Permenkeu No.60/PMK.07/2008.

Usaha untuk meningkatkan kesejahteraan masyarakat, pelayanan umum, dan daya saing daerah, maka pemda provinsi, kabupaten/kota mengatur dan mengurus sendiri urusan pemerintahan menurut asas otonomi. Dalam pelaksanaan program/kegiatan DBH-CHT; sebagai urusan pemerintahan yang kewenangan pengurusannya diserahkan kepada pemda penghasil CHT; kemudian TA 2010 selain daerah penghasil CHT dana tersebut dialokasikan juga pada daerah penghasil tembakau; dalam hal ini pemerintah memberikan kewenangan seluas-luasnya kepada pemda tersebut (prinsip otonomi seluas-luasnya) untuk mengurus dan mengatur urusan pemerintahan yang menjadi kewenangannya; oleh sebab itu dilakukan pembagian kewenangan yang didasarkan pada kriteria eksternalitas, akuntabilitas, dan efisiensi, sehingga masing-masing tingkat pemerintahan bisa mengetahui hak dan kewajibannya.

Selain itu dilaksanakan prinsip otonomi nyata; bahwa pemerintah provinsi, kabupaten/kota penghasil CHT yang mendapat alokasi dana CHT wajib melaksanakan ke-5 program/kegiatan yang ditetapkan dalam Pasal 66A (Ayat 1) UU No. 39/2007 berdasarkan tugas, wewenang, dan kewajiban yang senyatanya telah ada (pengaturannya telah ditetapkan dalam undang-undang dan peraturan pelaksanaan) dan berpotensi untuk tumbuh, hidup, dan berkembang sesuai dengan potensi dan kekhasan daerah; dalam hal ini Pemda harus menjabarkan lima (5) kegiatan utama dari penggunaan DBH CHT tersebut menjadi kegiatan yang lebih teknis sesuai dengan kebutuhan/prioritas masing-masing daerah; sebelum tahun anggaran berjalan Bupati/Walikota dan Gubernur diwajibkan membuat dan menyampaikan rancangan program/kegiatan dan penganggaran DBH-CHT; dengan demikian program/kegiatan yang dilaksanakan akan lebih sesuai dengan prioritas dan karakteristik daerah masing-masing.

Jean Blondel menyatakan: No goverment, even the most authoritarium, can ever take all public decisions at the centre. Some power has therefore 
to be given to authorities below the national level to take the decisions which the centre cannot take from this general remark emerges the idea of decentralisation, an idea which can of course take many forms and vary markedly in extent.

("Tak ada satupun pemerintahan, bahkan yang paling otoriter sekalipun, yang mampu mengambil semua keputusan publik dipusat. Karena itu sebagian kekuasaan harus diberikan kepada para penguasa dibawah level pemerintahan nasional guna mengambil keputusan-keputusan yang tidak bisa diambil oleh pemerintah pusat. Dari pernyataan umum inilah kemudian muncul gagasan desentralisasi, sebuah gagasan yang bisa mempunyai beragam bentuk dan sangat bervariasi tingkatannya")

Jadi kekuasaan atau kewenangan harus dibagi-bagi atau diserahkan kepada pemerintahan pada level pemerintahan daerah. ${ }^{9}$

Prinsip-prinsip tersebut diatas wujud dari adanya desentralisasi kekuasaan politik, antara lain pertama, ${ }^{10}$ dapat membantu mengembangkan nilai-nilai dan keterampilan demokrasi warga negara. Kedua, meningkatkan akuntabilitas dan responsivitas terhadap berbagai kepentingan dan urusan lokal. Ketiga, desentralisasi memberikan semacam saluran akses tambahan pada kekuasaan terhadap kelompok-kelompok yang secara historis marginal. Intinya Reformasi demokrasi negara-negara bangsa melalui pengembangan desentralisasi politik atau pemerintahan (politic or government decentralization), akan berdampak positif terhadap penguatan demokrasi.

Program/kegiatan DBH-CHT dari masing-masing provinsi, kabupaten/kota penghasil CHT berbeda antara satu dengan yang lain, karena tiap-tiap daerah memiliki karakteristik; misal ada provinsi, kabupaten/kota yang memiliki banyak pekerja/buruh pabrik rokoknya, sebaliknya lahan tanam tembakau tidak ada. Beda dengan daerah lain yang justru banyak petani tembakaunya, karena kondisi tanah dan iklim yang cocok untuk tanam tembakau. Selain itu penjelasan/alasan tentang perlunya pengadaan barang/peralatan sehubungan dengan pelaksanaan program/kegiatan, ditetapkan dengan peraturan gubernur/bupati/walikota; dengan

9 Jean Blondel, Comparative Government and Introduction, Florence : European University Institute, Philip Allan 66 Wood Lane End, Hemel Hempstead Hemtfondshire HP2RG Divisi Simon \& Schuster International Group, 1990.

${ }^{10}$ Svetlana Tsalik Ukuran dan Demokrasi: Alasan dan Dukungan untuk Desentralisasi. Yogyakarta: IRE Press, 2003, h. 156. 
demikian akan lebih memudahkan/mempercepat daerah dalam usaha pengadaan barang/peralatan yang dinilai urgen untuk segera direalisasikan untuk efektivitas pelaksanaan program/kegiatan DBH CHT. Serta prinsip otonomi yang bertanggungjawab; bahwa pengalokasian dana CHT, mewajibkan pemda penghasil CHT membuat program/kegiatan yang sejalan dengan tujuan dan maksud pemberian otonomi, yaitu memberdayakan daerah meningkatkan kesejahteraan rakyat sebagai bagian utama dari tujuan nasional, bahwa program/kegiatan alokasi dana CHT (AD-CHT) yang dibuat provinsi, kabupaten/kota, harus disertai dengan kajian bersama antara pihak-pihak terkait. Perancangan awal dari program/kegiatannya dibuat oleh SKPD-SKPD yang memiliki tugas dan fungsi sesuai dengan lima kegiatan utama. Biro/bagian perekonomian (membentuk Tim yang terdiri dari dinas-dinas pemda terkait) seperti: Disnaker, Disbun, Dinkes, Dinas Lingkungan Hidup, Disperindag. Diantara 5 kegiatan utama dana alokasi CHT (peningkatan kualitas bahan baku, pembinaan industri, pembinaan lingkungan sosial, sosialisasi ketentuan dibidang cukai, dan/atau pemberantasan barang kena cukai ilegal), terdapat 1 kegiatan yang membutuhkan adanya koordinasi dengan instansi diluar pemerintah daerah, yaitu kegiatan sosialisasi ketentuan dibidang cukai dan/atau pemberantasan barang kena cukai ilegal; dalam pelaksanaannya pemda dalam hal ini Disperindag membutuhkan adanya koordinasi dengan Kantor Pelayanan dan Pengawasan Bea \& Cukai (KPPBC) setempat, (yang merupakan Instansi Vertikal dari Ditjen Bea \& Cukai). Tim bentukan Biro/bagian perekonomian membuat program/kegiatan ADCHT sebagai penjabaran dari 5 kegiatan utama (yang limitatif ada dalam UU.No.39/2007 dan PMK No.84/2008). Untuk mencapai tujuan tersebut Tahun 2009 pemerintah melalui Ditjen Perimbangan Keuangan memberikan sosialisasi mengenai kebijakan DBH-CHT; melalui rapat pembahasan pembagian dan program kerja DBH CHT TA 2009 (di Surabaya, 23-12-2008). Sehubungan dengan hal tersebut Ditjen Perimbangan Keuangan menyarankan agar pemda (penghasil CHT) membentuk Bank Kegiatan.

Pendekatan politik menekankan pentingnya desentralisasi terhadap demokrasi, termasuk demokrasi partisipatoris ditingkat lokal. Desentralisasi 
menyediakan mekanisme yang memungkinkan tersalurkannya aspirasi politik masyarakat. Danny Burns et.al. mengajukan beberapa pendekatan umum untuk memperbaiki demokratisasi di tingkat lokal antara lain melibatkan masyarakat pada proses-proses politik secara langsung. ${ }^{11}$ Misalnya mekanisme dalam pemilihan kebijakan publik, bahwa desentralisasi partisipasi dalam pembuatan kebijakan publik dan kontrol terhadap pemerintah daerah bisa dilakukan masyarakat baik secara individual dan kelompok di luar pemerintah (civil society/masyarakat sipil). Mekanismenya misalnya melalui pertemuan-pertemuan dengan pemerintah daerah, keterlibatan langsung masyarakat dalam proses pembuatan kebijakan publik. ${ }^{12}$ Pelaksanaan program \& kegiatan alokasi dana CHT/DBH-CHT yang kewenangan pengurusannya diserahkan kepada pemda, memberikan semacam saluran akses tambahan pada kekuasaan terhadap kelompok-kelompok yang secara historis marginal (seperti buruh rokok, petani tembakau), sehingga apa dan bagaimana yang diinginkan oleh mereka bisa diakomodir. Program/kegiatan AD-CHT dirancang dan siap dibahas/dikaji oleh SKPD/dinas daerah terkait bersama dengan pelaku usaha; pengusaha, pekerja disektor rokok dan tembakau, petani tembakau, dan oganisasi masyarakat (Asosiasi Petani Tembakau yang ada di daerah, Asosiasi pengusaha Rokok),dll. Jadi ada pelibatan masyarakat pada proses pemilihan/pembuatan kebijakan DBHCHT. Setelah disepakati oleh berbagai pihak, hasil kesepakatan tersebut menjadi semacam Bank Kegiatan (bila perlu dituangkan dalam berita acara kesepakatan) agar timbul komitmen masing-masing pihak untuk melaksanakannya sesuai dengan apa yang telah disepakati. Hal ini menunjukkan adanya sisi akuntabilitas dan responsivitas terhadap berbagai kepentingan dan urusan lokal.

Regulasi desentralisasi atau otonomi daerah secara optimistik dipercaya beberapa kalangan akademisi sosial-politik dapat memperdalam demokratisasi politik di tingkat lokal. Regulasi desentralisasi atau otonomi daerah adalah

11 Muhammad Asfar, Implementasi Otonomi Daerah: Kasus Jatim, NTT, Kaltim, Surabaya: CPPS, CSSP dan Pusdeham, 2001, h. 208-209.

${ }^{12}$ George A. Boyne, Public Choice Theory and Local Government: A Comparative Analysis of the UK and the USA, London and New York: Macmillan and ST.Martin's, 1998, h. 6266. 
demokratis. ${ }^{13}$ Dasar argumentasinya, antara lain regulasi otonomi daerah dapat menumbuhkan tingkat partisipasi masyarakat dalam setiap proses pembuatan kebijakan dan dapat memperkuat akuntabilitas publik, sehingga masyarakat yakin bahwa kepentingannya tidak diabaikan.

Penyelenggaraan otoda harus berorientasi pada peningkatan kesejahteraan masyarakat dengan selalu memperhatikan kepentingan dan aspirasi yang tumbuh dalam masyarakat, oleh sebab itu seperti dijelaskan diatas, program/kegiatan alokasi CHT harus disesuaikan dengan kebutuhan, prioritas, dan ketersediaan anggaran untuk didanai dari APBD. Setiap tahun gubernur, bupati/walikota (dalam bentuk keputusan kepala daerah) menetapkan sebagian program/kegiatan AD-CHT yang telah disepakati tersebut.

Penyelenggaraan otoda harus menjamin keserasian hubungan antara daerah dengan daerah yang lainnya, artinya mampu membangun kerjasama antar daerah untuk meningkatkan kesejahteraan bersama dan mencegah ketimpangan antar daerah, misalnya daerah yang besar hasil tanaman tembakaunya dari pada industri tembakau maka menjalin kerjasama, dengan daerah yang memiliki industri tembakau, misal Pemkab Pamekasan (sebagai daerah penghasil tembakau) bekerjasama dengan Pemkot Surabaya (dalam hal ini Disperindag) kedua pihak tersebut menfasilitasi dan mengatur regulasinya; untuk kerjasama yang saling menguntungkan antara petani Pamekasan dengan industri tembakau (pabrik rokok) dikota Surabaya, seperti PT. Sampoerna, PT Wismilak. Pemkab Pamekasan juga menjalin kerjasama dengan pemkab Kudus Jateng, dikota tersebut terdapat pabrik rokok PT DJarum Kudus. Setiap tahun perusahaan Djarum membeli tembakau madura (Pamekasan dan Sumenep), Th 2008 s/d Th 2009 untuk Pamekasan pembelian PT Djarum minimal 3.500 ton - 4000 ton. Sedangkan harga beli selalu diatas Break Event Point (BEP) petani, misal harga pembelian ada yang Rp 24 Ribu hingga 36 Ribu. Ini mengindikasikan bahwa

13 Sri Djoharwinarlien, Otonomi: Peluang atau beban bagi daerah? Abdul Gaffar Karim et.al (ed.,) Kompleksitas Persoalan Otonomi Daerah di Indonesia, Yogyakarta: Pustaka Pelajar dan Jurusan Ilmu Pemerintahan FISIPOL UGM, 2003, h. 124. 
kerjasama antardaerah penting dilakukan agar bersinergi menghasilkan/meningkatkan kapasitas daerah, mengingat masing-masing daerah memiliki potensi, kondisi, dan kekhasan yang berbeda. Harapan Pemkab Pamekasan; pabrikan tetap konsisten dengan pembelian. Sebaliknya pemkab akan berupaya menjaga agar mutu tembakau tetap terjaga; (memberikan arahan agar petani tidak menanam didaerah "terlarang" seperti daerah pantai dan daerah persawahan. Sebab kalau klor terlalu tinggi akan mempengaruhi mutu dan kualitas; tembakau termasuk jenis tanaman tahunan yaitu tanaman yang dipanen hanya setahun sekali; oleh sebab itu tembakau tergolong dalam kelompok tanaman perkebunan. Pemkab Pamekasan dalam hal ini dinas perkebunan akan mengkomunikasikan dengan petani melalui Petugas Penyuluh Lapangan (PPL) mengenai apa yang menjadi keinginan dari pengusaha industri rokok. Pemkab Pamekasan juga bekerjasama dengan pabrik rokok di Kudus jawatengah (PT. Nojorono dan PT Sukun) pihak direksi mengatakan bahwa perusahaannya akan lebih selektif dalam membeli tembakau, hal itu seiring dengan tren global tembakau yang juga mulai mengalami penurunan produksi. (Lihat artikel sebelumnya: DBH-CHT ditinjau dari cukai rokok, kesehatan, dan industri rokok).

Pasal 2 (Ayat 4) UU No. 32/2004 bahwa pemda dalam menyelenggarakan urusan pemerintahan memiliki hubungan dengan pemerintah, dan dengan pemerintahan daerah lainnya; hubungan tersebut diantaranya adalah hubungan wewenang; yang dalam pelaksanaan kebijakan DBH-CHT direpresentasikan dalam wujud pembagian kewenangan antara pempus dengan pemda provinsi, kabupaten/kota, yang didasarkan pada kriteria yang meliputi eksternalitas, akuntabilitas, dan efisiensi. Hubungan kewenangan tersebut menimbulkan hubungan administrasi dan kewilayahan antar susunan pemerintahan. Selanjutnya Ayat 7 menyatakan bahwa hubungan administrasi terjadi sebagai konsekuensi dari kebijakan penyelenggaraan pemerintahan daerah yang merupakan satu kesatuan dalam penyelenggaraan sistem administrasi negara. Sedangkan hubungan kewilayahan terjadi sebagai konsekuensi dibentuk dan disusunnya daerah otonom yang diselenggarakan di wilayah NKRI; sehingga wilayah daerah merupakan satu kesatuan wilayah negara yang utuh dan bulat. Bertolak dari 
ketentuan tersebut diatas maka pembagian kewenangan dalam pelaksanaan kebijakan DBH-CHT membutuhkan: 1)Koordinasi antar pelaku pembangunan dalam pencapaian tujuan nasional; 2)Integrasi, sinkronisasi, dan sinergi antara pusat dan daerah; 3)Keterkaitan dan konsistensi antara perencanaan, penganggaran, pelaksanaan, dan pengawasan; 4)Penggunaan sumber daya secara efisien, efektif, berkeadilan, dan berkelanjutan; 5)Partisipasi masyarakat. ${ }^{14}$

Desentralisasi dapat meningkatkan demokrasi secara efektif, berkualitas, legitimate, dan stabil-terkonsolidasi. ${ }^{15}$ kebijakan DBH-CHT sejak perencanaan, penganggaran, pelaksanaan, hingga pengawasannya menerapkan konsolidasi antara pempus dengan pemda Prov/kota/kab. Hal ini sejalan dengan desentralisasi yang mensyaratkan adanya pembagian urusan pemerintahan antara pemerintah dengan daerah otonomi; pelaksanaan kebijakan DBH-CHT sebagai urusan pemerintahan yang bersifat Concurren; merupakan urusan pemerintahan yang pengurusannya pada bagian/bidang tertentu dilaksanakan bersama antara pemerintah dan pemda; sedangkan disisi yang lain ada bagian urusan yang menjadi kewenangan eksklusif pemerintah, dan ada pula bagian urusan yang diserahkan kepada provinsi/kabupaten/kota. ${ }^{16}$

Hal pembagian kewenangan yang didasarkan pada kriteria eksternalitas, akuntabilitas dan efisiensi tersebut, yaitu sebagai berikut:

1) Bagian tertentu dalam pelaksanaan program/kegiatan DBH-CHT yang dilaksanakan bersama antara pemerintah dengan pemda; misalnya dalam mekanisme pendistribusian DBH-CHT kepada provinsi penghasil CHT di lakukan melalui koordinasi antara pemerintah(Depkeu c.q Ditjen Bea dan Cukai, Ditjen Perimbangan Keuangan) dengan Gubernur dan Kantor wilayah Ditjen Bea dan Cukai setempat.

2) Bagian urusan dalam pelaksanaan program/kegiatan DBH-CHT yang menjadi kewenangan pemerintah; misalnya:

- Menteri Keuangan harus mempertimbangkan \& meneliti tentang keakuratan pembagian alokasi DBH-CHT tersebut apakah sudah sesuai dengan ketentuan peraturan perundang-undangan sampai

\footnotetext{
${ }^{14}$ Penjelasan UU. No.17/2007 tentang Rencana Pembangunan Jangka Panjang Nasional Tahun 2005- 2025, Bagian Ketentuan Umum.

${ }^{15}$ Tsalik, 2003:154; Sorensen, 2003: 236; Goodin dan Klingemann, 1996:633

${ }^{16}$ Bagian Penjelasan Undang-undang No.32/2004, Op.Cit, mengenai Pembagian Urusan Pemerintahan.
} 
akhirnya menutuskan untuk menyetujui dan menetapkan alokasi DBH-CHT tersebut.

- Pemerintah dalam hal ini menteri keuangan/menkeu memberikan pedoman umum penggunaan DBH-CHT dan sanksi atas penyalahgunaan alokasi DBH-CHT. Dalam penyaluran DBH-CHT Menkeu selaku pengguna anggaran transfer kedaerah ${ }^{17}$ mempunyai kewenangan atas pelaksanaan anggaran transfer kedaerah dengan cara menunjuk Dirjen Perimbangan Keuangan sebagai kuasa pengguna anggaran transfer ke daerah; yang kemudian akan melaksanakan kewenangan dari menkeu terkait dengan penyaluran DBH CHT tersebut.

- Upaya pembinaan atas pelaksanaan DBH-CHT didaerah dilaksanakan oleh pemerintah dan atau Gubernur selaku wakil pemerintah didaerah untuk mewujudkan tercapainya tujuan penyelenggaraan otoda; pembinaan meliputi: a) Koordinasi pemerintahan antar susunan pemerintahan; meliputi aspek perencanaan, dan evaluasi dalam pelaksanaan program/kegiatan DBH-CHT; b)Pemberian pedoman dan standar dalam pelaksanaan program/kegiatan DBH-CHT; yang mencakup aspek perencanaan, pelaksanaan, tata laksana, pendanaan, kualitas, pengendalian dan pengawasan; c)Pemberian bimbingan, supervisi, dan konsultasi; yang mencakup aspek perencanaan, pelaksanaan, tata laksana, pendanaan, kualitas, pengendalian dan pengawasan; d)Pemantauan dan Evaluasi atas laporan alokasi penggunaan anggaran yang dilakukan oleh Menkeu RI c.q Dirjen Perimbangan Keuangan ${ }^{18}$, selanjutnya dikoordinasikan dengan Mendagri; karena tugas dan fungsi Mendagri yang diantaranya meliputi pemantauan dan evaluasi yang antara lain dilakukan terhadap kewenangan, kelembagaan, kepegawaian, keuangan, pengelolaan aset, LPND, DPRD, pelayanan publik, dan kebijakan daerah. ${ }^{19}$

3) Bagian urusan dalam pelaksanaan program/kegiatan DBH-CHT yang diserahkan pada provinsi; misalnya:

- Gubernur daerah penghasil CHT menetapkan alokasi DBH-CHT untuk provinsi/kabupaten/kota diwilayahnya.

- Gubernur bertanggungjawabmengerakkan,mendorong, dan melaksanakan kegiatan sesuai dengan prioritas dan karakteristik daerah masing-masing.

- Pada awal tahun gubernur membuat dan menyampaikan rancangan program \& kegiatan DBH CHT dan penganggarannya. Program \& kegiatan DBH CHT tersebut merupakan penjabaran dari Pasal 66

${ }^{17}$ Pasal 6 Peraturan Menteri Keuangan No.21/PMK.07/2009 tentang Pelaksanaan dan Pertanggungjawaban Anggaran Transfer Ke Daerah.

18 Pasal 13 (Ayat 1) Peraturan Menteri Keuangan No.84/PMK.07/2008 tentang Penggunaan DBH-CHT dan sanksi atas penyalahgunaan alokasi DBH-CHT.

${ }^{19}$ Pasal 14 dan 17 Peraturan Pemerintah No.79/2005 tentang Pedoman Pembinaan dan Pegawasan Penyelenggaraan Pemerintahan Daerah. 
A UU Cukai, kemudian gubernur melakukan konsolidasi rancangan program \& kegiatan dengan bupati/walikota. Selanjutnya hasil konsolidasi tersebut disampaikan kepada Menkeu c.q Ditjen Perimbangan Keuangan dan Mendagri c.q Dirjen Bina Administrasi Keuangan daerah. ${ }^{20}$

- Pengadaan barang dalam rangka pelaksanaan program/kegiatan DBH CHT, di Tk.Provinsi dilaksanakan dengan keputusan gubernur.

- Gubernur membuat laporan alokasi/penggunaan DBH-CHT atas pelaksanaan program/kegiatan sebagai penjabaran dari lima kegiatan utama (Pasal 66 A (Ayat 1) UU Cukai). Program/kegiatan yang dibuat/dirancang oleh pemerintah provinsi penghasil CHT merupakan program/kegiatan yang disesuaikan dengan kondisi, prioritas atau kebutuhan daerah. Kemudian gubernur membuat laporan konsolidasi penggunaan DBH CHT/ alokasi dana CHT, untuk memantapkan atau memperkuat penganggaran atas penggunaan DBH CHT yang telah dibuat oleh gubernur, bupati/walikota. Laporan konsolidasi tersebut diserahkan setiap 6 bulan sekali; kepada MenKeu dan Mendagri. ${ }^{21}$ (Menkeu c.q Ditjen Perimbangan Keuangan dan Mendagri cq. Ditjen Bina Administrasi Keuangan Daerah). ${ }^{22}$

4) Bagian urusan dalam pelaksanaan program DBH-CHT yang diserahkan kepada Kabupaten/Kota; misalnya: a) Bupati/Walikota bertanggungjawab untuk menggerakkan, mendorong, dan melaksanakan kegiatan sesuai dengan prioritas dan karakteristik daerah masing-masing; b) Bupati/Walikota membuat dan menyampaikan rancangan program kegiatan dan penganggaran DBH-CHT kepada gubernur sebelum tahun anggaran berjalan; c) Pengadaan barang dalam rangka pelaksanaan program/kegiatan DBH CHT, di Tk.Kab/kota dilaksanakan dengan keputusan Bupati/Walikota; d) Bupati/Walikota membuat laporan Alokasi Penggunaan Dana atas pelaksanaan program/kegiatan sebagai penjabaran dari Lima kegiatan utama (Ps. 66 A (Ayat 1) UU Cukai), rancangan program dan kegiatan yang dibuat/dirancang oleh pemda kabupaten/kota penghasil CHT tersebut disesuaikan dengan prioritas dan karakteristik daerah masing-masing. Laporan tersebut dikirim setiap 6 bulan sekali kepada gubernur.

Poin 3 dan 4 merupakan bentuk pertanggungjawaban desentralisasi dengan menggunakan mekanisme partisipatory. Sebagaimana konsep berikut ini;

"UNDP mengkonseptalisasikan desentralisasi sebagai berikut: Desentralisasi sektor publik dengan sendirinya tidak akan dapat efektif

\footnotetext{
${ }^{20}$ PMK. No.84/PMK.07/2008, Op.cit., Pasal 10 (Ayat 2).

${ }^{21}$ Ibid, Pasal 11 (Ayat 2).

${ }^{22}$ Ibid, Pasal 10 (Ayat 2).
} 
mendukung penguatan pemerintah lokal, termasuk penguatan masyarakat pada sektor publik dan privat. Dan sebaliknya pencapaian good governance pada tingkat lokal tidak mungkin tercapai tanpa transfer tanggungjawab dan kapasitas melalui desentralisasi. Tema "desentralisasi pemerintahan" memberikan pengertian sistematik dan harmoni bahwa hubungan timbal balik melahirkan keseimbangan kekuasaan dan responsibilitas antara pempus dengan level pemerintahan lain dan aktoraktor non pemerintah, dan kapasitas lembaga di tingkat lokal mempertanggung-jawabkan desentralisasi menggunakan mekanisme partisipatory". 23

Hasil kesepakatan sejumlah stage holder dalam perancangan dan pembahasan Program/kegiatan AD-CHT dituangkan dalam bentuk semacam Bank Kegiatan (ada berita acara kesepakatan) sehingga timbul komitmen masingmasing pihak untuk melaksanakan sesuai dengan apa yang telah disepakati. Hal ini menunjukkan adanya sisi akuntabilitas dan responsivitas terhadap berbagai kepentingan dan urusan lokal.

Diatas dinyatakan bahwa bagian urusan yang menjadi kewenangan pemerintah dalam pelaksanaan prog/kegiatan DBH-CHT al: pemerintah dan gubernur melakukan pembinaan dalam bentuk bimbingan, supervisi, dan konsultasi yang mencakup antara lain: aspek pemantauan dan evaluasi, yaitu: Pemda kabupaten/kota penghasil CHT dan penghasil tembakau diwajibkan membuat rancangan program dan kegiatan disesuaikan dengan prioritas dan karakteristik daerah masing-masing. Kemudian bupati/walikota membuat laporan Alokasi Penggunaan Dana atas pelaksanaan program/kegiatan sebagai penjabaran dari Lima kegiatan utama (Ps. 66 A (Ayat 1) UU Cukai), Laporan tersebut dikirim setiap 6 bulan sekali kepada gubernur.

Sedangkan pemerintah provinsi penghasil CHT dan penghasil tembakau juga membuat/merancang program/kegiatan DBH-CHT disesuaikan dengan kondisi, prioritas/kebutuhan daerah. Setelah itu gubernur wajib mengirimkan laporan alokasi/penggunaan DBH-CHT atas pelaksanaan program/kegiatan

$23 \mathrm{Jr}$ Arellano A. Colongon, What is Happening of The Ground? The Progres of Decentralisation, Edward Aspinall and Greg Fealy (eds.,) Local Power and Politics in Indonesia: Decentralisation and Democratisation, Singapore: Institue of Southeast Asian Studies, 2003, h. 89. 
sebagai penjabaran dari lima kegiatan utama (Pasal 66 A (Ayat 1) UU Cukai). Selain itu gubernur membuat laporan konsolidasi penggunaan DBH CHT/ alokasi dana $C H T$, untuk memantapkan atau memperkuat penganggaran atas penggunaan DBH CHT yang telah dibuat oleh gubernur, bupati/walikota. Laporan konsolidasi tersebut diserahkan setiap 6 bulan sekali; kepada Menkeu dan Mendagri. ${ }^{24}$ (Menkeu c.q Ditjen Perimbangan Keuangan dan Mendagri cq. Ditjen Bina Administrasi Keuangan Daerah)

Urusan pemerintahan yang menjadi kewenangan pemda provinsi, kabupaten/kota yang didasarkan pada kriteria eksternalitas, akuntabilitas, dan efisiensi; terdiri atas urusan wajib dan urusan pilihan. Urusan wajib yang menjadi kewenangan dari masing-masing pemerintahan daerah, pada dasarnya memiliki kesamaan, yang membedakan hanya skalanya; ada urusan wajib yang berskala propinsi (skala provinsi; urusan wajibnya meliputi juga lintas kabupaten/kota) dan ada urusan wajib yang berskala kabupaten/kota. Urusan wajib dalam pelaksanaan program/kegiatan DBH-CHT yang menjadi kewenangan daerah provinsi, kabupaten/kota; antara lain:

1. Bidang Perencanaan dan pengendalian pembangunan;

a. Perencanaan dalam pelaksanaan program/kegiatan DBH-CHT; misalnya:

- Koordinasi gubernur dengan Kanwil Ditjen Bea dan Cukai dalam penetapan alokasi DBH-CHT untuk provinsi,kabupaten/kota yang ada dalam penguasaannya. Kanwil DJBC memberikan data tentang perkiraan CHT per kabupaten/kota, selanjutnya pembagian DBHCHT tersebut disampaikan ke Menkeu untuk mendapatkan persetujuan dan penetapan.

- Bupati/walikota, gubernur pada awal tahun membuat dan menyampaikan rancangan program/kegiatan (penjabaran dari 5 kegiatan utama Pasal 66 A UU Cukai), kemudian membuat dan menyampaikan penganggarannya dan gubernur mengkonsolidasikan rancangan program/kegiatan dengan bupati/walikota. Hasil konsolidasi tersebut disampaikan kepada Menkeu c.q Dirjen Perimbangan Keuangan dan Mendagri c.q Dirjen Bina Administrasi Keuangan Daerah.

b. Pengendalian dalam Pelaksanaan Program/kegiatan DBH-CHT; terdiri atas:

${ }^{24}$ Ibid, Pasal 11 (Ayat 2). 
- Pengendalian terhadap kebijakan perencanaan program/kegiatanDBH-CHT; misal: Biro Administrasi Perekonomian Provinsi, Bidang Perekonomian Kabupaten/Kota selaku Sekretariat dalam pelaksanaan program/kegiatan DBH-CHT; melakukan monitoring terhadap pelaksanaan kebijakan penggunaan DBH-CHT, dan melaporkan hasil pelaksanaan penggunaan DBHCHT kepada Bappeda; kemudian Bappeda melaporkan hasil pemantauan atas pelaksanaan penggunaan DBH-CHT kepada kepala daerah.

- Pengendalian pelaksanaan rencana program/kegiatan DBH-CHT; misal:

(1) Pengendalian oleh gubernur, bupati/walikota dalam pelaksanaan program/kegiatan DBH-CHT dilakukan oleh Kepala SKPD penerima dana alokasi CHT sesuai dengan tugas pokok dan fungsinya; SKPD tersebut adalah Disnaker, Disperindag, Disbun, Dinas Koperasi dan UMKM, Dinas Sosial, Badan Lingkungan Hidup, dan Dinas Kesehatan/RSU/RSK. Perlu diketahui bahwa pengaturan mengenai SKPD mana saja yang menerima dana alokasi CHT tergantung pada kebutuhan, dan prioritas daerah. Pengendalian oleh Kepala SKPD meliputi pemantauan pelaksanaan program dan kegiatan yang meliputi realisasi pencapaian target, penyerapan dana, dan kendala yang dihadapi.

(2) Hasil pemantauan dari pelaksanaan program dan kegiatan DBH-CHT disusun dalam bentuk laporan setiap 6 bulan $1 \mathrm{x}$ untuk disampaikan kepada Biro administrasi Perekonomian.

(3) Sebagai perangkat daerah yang melakukan pengendalian terhadap keseluruhan perencanaan pembangunan daerah; Kepala Bappeda provinsi, kabupaten/kota; melaporkan hasil pemantauan yang telah dilakukannya, berikut juga dengan hasil pemantauan yang dilakukan oleh SKPD kepada Kepala daerah, disertai dengan rekomendasi dan langkah-langkah yang diperlukan.

2. Penanganan bidang kesehatan, misal: Program: a) Pengadaan, peningkatan sarana dan prasarana RS/RSJ/RSPP/RSM; melalui kegiatan pengadaan alat-alat kesehatan rumah sakit. b) Pengembangan lingkungan sehat; melalui kegiatan pembentukan area bebas rokok pada instansi.

3. a) Penyelenggaraan pendidikan dan alokasi sumber daya manusia potensial, misal: Program Pendidikan non formal; melalui kegiatan sosialisasi bahaya akibat merokok bagi generasi muda, pegawai negeri, tenaga kerja wanita. b) Promosi kesehatan dan pemberdayaan masyarakat; melalui kegiatan penyuluhan kesehatan akibat rokok; pengadaan media promosi dan informasi sadar hidup sehat; TOT pencegahan merokok usia dini. c) Dll.

4. Pelayanan bidang ketenagakerjaan, misal: program peningkatan kualitas dan produktivitas tenaga kerja dan identifikasi kebutuhan layanan dan 
pembinaan ketenagakerjaan disektor industri rokok; melalui kegiatan pelatihan peningkatan keterampilan kerja; pendidikan \& pelatihan keterampilan bagi pekerja perusahaan rokok.

5. Fasilitas pengembangan koperasi, usaha kecil, dan menengah; misal: a) program peningkatan kualitas bahan baku; melalui kegiatan fasilitasi kemitraan usaha tani tembakau. b)pengembangan industri kecil dan menengah; melalui pendataan industri kecil menengah.

6. Bidang pengendalian lingkungan hidup, misal: program peningkatan keamanan dan kenyamanan lingkungan; melalui kegiatan: pengendalian kebisingan dan gangguan kegiatan akibat industri rokok; pemeriksaan laboratorium hasil uji kualitas limbah cair domestik; sosialisasi pengelolaan lingkungan untuk pabrik rokok; pengujian udara ambient dikawasan industri rokok.

7. Urusan wajib lainnya yang diamanatkan oleh peraturan perundangundangan, misal, program: a) peningkatan pendapatan daerah; melalui sosialisasi ketentuan dibidang cukai rokok. b)pembinaan industri rokok; melalui penyusunan dokumen hasil pemetaan pabrik rokok. c)peningkatan kualitas bahan baku; melalui pendataan kualitas bahan baku; tembakau

Penyelenggaraan pembagian kewenangan berdasarkan kriteria eksternalitas, akuntabilitas dan efisiensi dalam pelaksanaan program/kegiatan DBH-CHT selain merupakan urusan wajib juga menjadi urusan pilihan bagi provinsi, kabupaten/kota penghasil CHT. Urusan pemerintahan provinsi, kabupaten/kota yang bersifat wajib merupakan urusan pemerintahan yang berpedoman pada standar pelayanan minimal, dilaksanakan secara bertahap, dan ditetapkan oleh pemerintah, seperti penanganan bidang kesehatan, pendidikan, penanganan masalah sosial, perencanaan dan pengendalian pelaksanaan rencana pembangunan. Sedangkan urusan pemerintahan provinsi, kabupaten/kota yang bersifat pilihan, meliputi urusan pemerintahan yang secara nyata ada dan berpotensi meningkatkan kesejahteraan masyarakat sesuai dengan kondisi, kekhasan, dan potensi unggulan daerah, yang dalam hal ini daerah tersebut antara lain: a) Berpotensi menghasilkan penerimaan bagi negara, yaitu dari $\mathrm{CHT}$; b) Daerah yang memiliki potensi sebagai daerah penghasil bahan baku produk hasil tembakau (luas areal perkebunan tembakau); c) Daerah yang sebagian warganya bekerja sebagai buruh/pekerja pabrik industri tembakau; d) Daerah yang memiliki industri hasil tembakau/pabrik rokok; e) Luas areal pabrik rokok yang terdapat di daerah kabupaten/kota penghasil CHT. kelima hal tersebut diatas menjadi 
indikator yang menentukan besaran jumlah bagian DBH-CHT yang akan dialokasikan ke kabupaten/kota daerah penghasil CHT.

\section{Kesimpulan}

Pembagian kewenangan tersebut diatas telah memenuhi: 1)kriteria eksternalitas (mempertimbangkan dampak/akibat yang ditimbulkan dari suatu penyelenggaraan urusan pemerintahan); apabila dampak yang ditimbulkan bersifat lokal maka urusan pemerintahan tersebut menjadi kewenangan kabupaten/kota, apabila dampaknya bersifat regional maka menjadi kewenangan provinsi, dan apabila dampaknya bersifat nasional maka menjadi kewenangan pemerintah. 2)kriteria akuntabilitas bahwa tingkat pemerintahan yang menangani sesuatu bagian urusan adalah tingkat pemerintahan yang lebih langsung/dekat dengan dampak/akibat dari urusan yang ditangani tersebut; sehingga akuntabilitas penyelenggaraan bagian urusan pemerintahan tersebut kepada masyarakat akan lebih terjamin. 3)kriteria efisiensi; yaitu pembagian kewenangan urusan pemerintahan yang mempertimbangkan tersedianya sumber daya (personil, dana, dan peralatan) untuk mendapatkan ketepatan, kepastian, dan kecepatan hasil yang harus dicapai dalam penyelenggaraan bagian urusan; artinya apabila suatu bagian urusan dalam penanganannya dipastikan akan lebih berdaya guna dan berhasil guna dilaksanakan oleh provinsi dan/atau kabupaten/kota dibandingkan apabila ditangani oleh pemerintah maka bagian urusan tersebut diserahkan kepada provinsi dan/atau kabupaten/kota. Sebaliknya apabila bagian urusan akan lebih berdaya guna dan berhasil guna bila ditangani oleh pemerintah maka bagian urusan tersebut tetap ditangani oleh pemerintah. Penyelenggaraan urusan pemerintahan yang dibagi berdasarkan kriteria eksternalitas, akuntabilitas dan efisiensi tersebut dalam pelaksanaannya memperhatikan keserasian hubungan antar susunan pemerintahan; ini merupakan bentuk pelaksanaan hubungan kewenangan antara pemerintah dengan pemerintah daerah (provinsi,kabupaten/kota) atau antar pemerintahan daerah; bahwa pengelolaan bagian urusan pemerintahan yang dikerjakan oleh tingkat pemerintahan yang berbeda bersifat saling berhubungan (interkoneksi), saling tergantung (interdependensi), dan saling mendukung sebagai satu kesatuan sistem 
pemerintahan dengan memperhatikan cakupan kemanfaatan. Pembagian urusan dalam pelaksanaan program/kegiatan DBH-CHT tersebut membawa dampak positif bagi peningkatan penerimaan negara dari sektor cukai; misal TA 2008 walaupun merupakan tahun pertama pelaksanaan kebijakan alokasi dana CHT kedaerah tapi cukup memberi dampak yang menggembirakan,terbukti adanya peningkatan di APBN TA 2009 penerimaan negara dari sektor CHT mencapai Rp 48.240.100.000.000,- meningkat dibandingkan penerimaan CHT dalam APBNPerubahan TA 2008 yang berjumlah Rp 44.533.900.000.000,-

\section{Daftar Pustaka}

Asfar, Muhammad (ed.,), Implementasi Otonomi Daerah: Kasus Jatim, NTT, Kaltim, Surabaya: CPPS, CSSP dan Pusdeham, 2001.

Blondel, Jean, Comparative Government and Introduction, Florence: Simon \& Schuster International Group, 1990.

Boyne, George A. Public Choice Theory and Local Government: A Comparative Analysis of The UK and USA. London and New York: Macmillan and ST. Martin's, 1998.

Djoharwinarlien, Sri. Otonomi: Peluang atau beban bagi daerah? Abdul Gaffar Karim et.al. Kompleksitas Persoalan Otonomi Daerah di Indonesia, Yogyakarta: Pustaka Pelajar dan Jurusan Ilmu Pemerintahan FISIPOL UGM, 2003.

Nasution, Arif M., et.al. Demokratisasi dan Problema Otonomi Daerah. Bandung: Mandar Maju, 2000.

Rasyid, M. Ryaas, ’Regional Autonomy and Local Politics in Indonesia”, Edward Aspinall and Greg Fealy (eds.,), Local Power and Politics in Indonesia:Decentralisation and Democratisation, Singapore: Institute of Southeast Asian Studies, 2003.

Sorensen, Georg. Demokrasi dan Demokratisasi: Proses dan Prospek dalam Sebuah Dunia yang Sedang Berubah, Yogyakarta: CCSS dan Pustaka Pelajar, 2003.

Sugianto, Pengantar Kepabeanan dan Cukai, Grasindo Jakarta: Widiasarana, 2008 
242 Yuridika: Volume 28 No 2, Mei - Agustus 2013

\section{Peraturan Perundang-undangan}

Undang-undang No.17/2003 tentang Keuangan Negara

Undang-undang No.32/2004 tentang Pemerintahan Daerah

Peraturan Pemerintah No.79/2005 tentang Pedoman Pembinaan dan Pengawasan Penyelenggaraan Pemerintahan Daerah.

Peraturan Pemerintah No. 7/2008 tentang dekonsentrasi dan tugas pembantuan

Peraturan Menteri Keuangan No. 60/PMK.07/2008 tentang Dana Alokasi CHT TA 2008

Peraturan Menteri Keuangan No. 84/PMK.07/2008 tentang Penggunaan Dana Bagi Hasil (DBH) CHT dan Sanksi Atas Penyalahgunaan Alokasi DBH CHT.

Peraturan Menteri Keuangan No. 100/PMK.01/2008 tentang Organisasi, dan Tata Kerja Departemen Keuangan.

Peraturan menteri Keuangan No.21/PMK.07/2009 tentang Pelaksanaan dan Pertanggungjawaban Anggaran Transfer ke Daerah. 